\title{
IMPROVING THE METHOD APPROACH TO THE RATING EVALUATION OF EMPLOYEES AS PROFESSIONAL CAREER DEVELOPMENT
}

\author{
Serhii Makarenko', Nataliia Oliinyk ${ }^{2}$, Tatyana Kazakova ${ }^{3}$
}

\begin{abstract}
Theoretical and methodical aspects of rating performance appraisal of academic workers of higher educational institutions are the object of research. The purpose of the article is to study peculiarities of the functioning of institutions of higher education and to improve processes of rating assessment of employees as a part of the development of professional careers. Methodological basis of research consisted of scientific works of domestic and foreign scientists and leading specialists, statistical and analytical materials of state authorities. Results are obtained through the use of methods: statistical and economic - to determine the peculiarities and trends of the development of institutions of higher education in Ukraine; economics and mathematics - to study the impact of the main indicators of activity and performance of higher education institutions and purchasing power of the population on the total volume of gross domestic product; abstract-logical - for theoretical generalization and formulation of conclusions. The results of the conducted research testify to the necessity of introducing a set of measures for optimization of labour costs for scientific and pedagogical workers of higher education institutions without worsening the quality of provided educational services. It has been revealed that the lack of a sound methodological approach to employee rating and appropriate means of motivation for professional development can lead to the loss of existing intellectual potential and competitive positions of higher education institutions in the market for educational services in general. To maintain the existing intellectual potential justified the introduction of an organizational and economic system for optimizing labour costs, which should consist of the following five main stages: collecting information, processing information received using expert and econometric and mathematical models, calculating the predictive values of factors and productive indicator, development of measures and directions of optimization of labour costs, development of a system of planning career development of personnel. With the introduction of a rating assessment of the activities of academic workers and its attachment to the development of professional careers, it is necessary to avoid possible professional burnout due to overload. A further study of the mechanism of determining the optimal predictive model, taking into account the influence of the shadow sector on the official statistical indicators of the development of the economy and the educational sector, in particular, deserves further study.
\end{abstract}

Key words: academic workers, rating estimation, professional career, pay, coefficient of competence, multiple linear regression.

\section{JEL Classification: M12, M54}

\section{Introduction}

In today's operating conditions, the most important task of ensuring the effective operation of business entities of all forms of ownership is the permanent introduction of measures is optimize production costs without degrading the quality of made products, work performed, services rendered.
The absence of the necessary sources of financing for the development of the educational sector in the state and local budgets, reducing the purchasing power of the population and, consequently, reducing the number of potential students and listeners, and optimizing the costs of economic activity, also need domestic institutions of higher education.

\footnotetext{
Corresponding author:

${ }^{1}$ Kherson State University, Ukraine.

E-mail: makar0684@gmail.com

ORCID: http://orcid.org/0000-0001-9929-8967

${ }^{2}$ Kherson National Technical University, Ukraine.

E-mail: nat-o@ukr.net

ORCID: http://orcid.org/0000-0002-1019-5708

${ }^{3}$ Kherson State University, Ukraine.

E-mail: textil.ks@gmail.com
} 
Taking into account that the largest share of the costs related to the functioning of higher education institutions is borne by the expenses of the payment of the work of pedagogical and scientific and pedagogical workers, one of the main directions of their optimization is the definition of a reasonable number of employees for the provision of quality educational services. At the same time, in order not to lose the accumulated intellectual potential, the top management of institutions of higher education should develop an effective system for optimizing labour costs taking into account the quality of educational services and the potential contingent of future students, students, postgraduates and doctoral students, with the simultaneous introduction of a phased system of career development for employees who effectively and in a timely manner fulfil the established functional responsibilities and are engaged in self-development within defined curricula and scientific international grants. The indicated determines the relevance of the topic of research, its purpose, and content.

The purpose of the article is to study peculiarities of the functioning of institutions of higher education and to improve processes of rating assessment of employees as a part of the development of professional careers.

The methodological basis of research consisted of scientific works of domestic and foreign scientists and leading specialists, statistical and analytical materials of state authorities. Results are obtained through the use of methods: statistical and economic - to determine the peculiarities and trends of the development of institutions of higher education in Ukraine; economics and mathematics - to study the impact of the main indicators of activity and performance of higher education institutions and purchasing power of the population on the total volume of gross domestic product; abstract-logical - for theoretical generalization and formulation of conclusions.

\section{Literature review}

Some aspects of the study of the labour activity of the population and the individualization of the processes of training and development of employees were investigated in analytical works of A. A. Derkach, V. H. Zazykyn \& A. K. Markova (2000), V. T. Lozovetska (2015), H. Pivniak, O. Aziukovskyi, M. Trehub \& A. Bardas (2017), S. O. Tsymbaliuk (2017), N.A. Tyukhtenko (2016). Improvement of the processes for managing the professional development of workers was dealt with by L. I. Beztelesna \& A. V. Pecheniuk (2016), O. Herasymenko (2003), B. A. Kaminskyi (2006), B. I. Mokin \& Yu. V. Marymonchyk (2004), O. H. Obmok (2014), O. V. Skibitska (2004). Despite significant work, there remain problems that require additional scientific analysis, especially as regards the improvement of professional development processes, based on the coordination of the interests of the institution of higher education and career strategies of the individual through the introduction of objective rating assessment.

\section{Development of an organizational and economic system for the optimization of labour costs}

Improvement of processes of professional career development of personnel, including academic workers of higher education institutions, is one of the most important elements for ensuring the effective operation and development of business entities of all forms of ownership. The lack of a well-founded system for assessing business activity and proper means of motivation at each stage of a scientific and pedagogical career can lead to the loss of incentives by subordinate employees to permanent self-improvement and qualitative and timely implementation of their assigned functional responsibilities. At the same time, in the conditions of the total lack of funds in the State Budget of Ukraine for the development of the educational sector, for the maintenance of the existing intellectual potential, the primary introduction of a substantiated organizational and economic system for optimizing labour costs is necessary.

The said system should have the following five main stages: collecting information, processing received information using expert and econometric and mathematical models, calculating predictive values of factors and the effective indicator, developing measures and directions for optimizing labour costs, developing a system for planning a career development (Figure 1).

\section{Analysis of the performance indicators of higher education institutions}

Using the knowledge and experience of the leading experts of the educational sector, local authorities, budgeting enterprises and organizations of Kherson (Kherson region, Ukraine), the influence of the main indicators of activity and efficiency of institutions of higher education and purchasing power of the population on the total volume of the gross domestic product was investigated. According to respondents' opinion, the following indicators have the greatest influence on the total gross domestic product: the average number of economically active population aged 15-70; number of graduates from higher education institutions; the number of persons who graduated from the postgraduate study; the number of people who have completed doctoral studies; real wage index. The necessary materials for further processing and determining the reliability and validity of building a forecast model of development in the dynamics of 2010-2017 years is reflected in Table 1. 


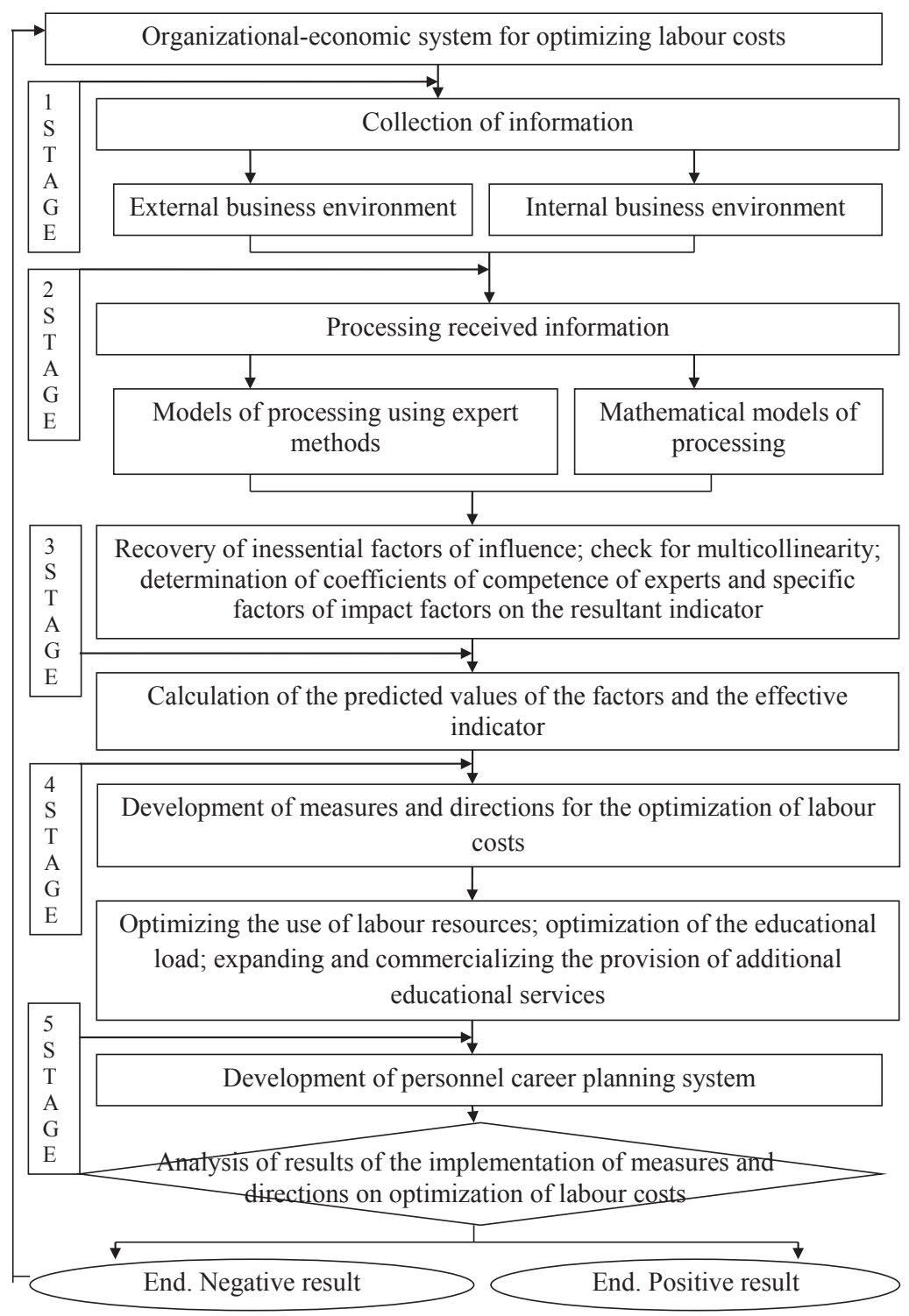

Figure 1. The organizational and economic system of optimization of labour costs

Source: developed by the authors

Table 1

Necessary materials for further processing and determination of reliability and validity of construction of the forecast model of development in the dynamics of 2010-2017 years

\begin{tabular}{|c|c|c|c|c|c|c|}
\hline Years & $\begin{array}{c}\text { Gross domestic } \\
\text { product at } \\
\text { constant prices } \\
\text { in 2010, UAH } \\
\text { million (Y) }\end{array}$ & $\begin{array}{c}\text { The average number } \\
\text { of economically } \\
\text { active population } \\
\text { aged 15-70, thousand } \\
\text { persons }\left(\mathrm{X}_{1}\right)\end{array}$ & $\begin{array}{c}\text { Number of } \\
\text { graduates from } \\
\text { institutions of } \\
\text { higher education, } \\
\text { persons }\left(\mathrm{X}_{2}\right)\end{array}$ & $\begin{array}{c}\text { The number of } \\
\text { persons who } \\
\text { graduated from the } \\
\text { postgraduate study, } \\
\text { persons }\left(\mathrm{X}_{3}\right)\end{array}$ & $\begin{array}{c}\text { The number of } \\
\text { persons who } \\
\text { completed doctoral } \\
\text { studies, persons } \\
\left(\mathrm{X}_{4}\right)\end{array}$ & $\begin{array}{c}\text { Real wage index, } \\
\%\left(\mathrm{X}_{5}\right)\end{array}$ \\
\hline 2010 & 1079346 & 20894,1 & 636291 & 8092 & 450 & 110,2 \\
\hline 2011 & 1138338 & 20893,0 & 609033 & 8350 & 483 & 108,7 \\
\hline 2012 & 1141055 & 20851,2 & 595251 & 8292 & 418 & 114,4 \\
\hline 2013 & 1140750 & 20824,6 & 560381 & 8075 & 566 & 108,2 \\
\hline 2014 & 1066001 & 19920,9 & 484482 & 7597 & 524 & 93,5 \\
\hline 2015 & 961821 & 18097,9 & 447418 & 7493 & 563 & 79,8 \\
\hline 2016 & 985299 & 17955,1 & 386668 & 6703 & 551 & 109,0 \\
\hline 2017 & 1009931 & 17854,4 & 421131 & 6087 & 543 & 119,1 \\
\hline
\end{tabular}

Source: official site of the State Statistics Service of Ukraine 
The formula was used for calculating the correlation coefficients; the following relationship was established between the performance indicator $(\mathrm{Y})$ and the factors indicated:

- $\mathrm{r}_{\mathrm{yx} 1}=0,9319$ - in accordance with the scale of the assessment of the relationship of variables, the relationship between $\mathrm{Y}$ and $\mathrm{X}_{1}$ is considered very high, and, therefore, the effect of this factor on the final result is significant and the figure indicated by the model should be included;

- $\mathrm{r}_{\mathrm{y} \times 2}=0,839$ - the connection between $\mathrm{Y}$ and $\mathrm{X}_{2}$ is considered high;

- $r_{\mathrm{yx} 3}=0,7648$ - the connection between $\mathrm{Y}$ and $\mathrm{X}_{3}$ is considered higher than average;

- $r_{\mathrm{yx} 4}=-0,5691$ - the connection between $\mathrm{Y}$ and $\mathrm{X}_{4}$ is considered average;

- $r_{\mathrm{yx} S}=0,4334-$ the connection between $\mathrm{Y}$ and $\mathrm{X}_{5}$ is considered lower than the average.

At the same time, calculations show that the growth of the $\mathrm{X}_{4}$ indicator (the number of people completing doctoral studies) has a negative impact on the overall performance $\mathrm{Y}$ (gross domestic product at constant prices in 2010). The above can be argued that in the current conditions of development of science in Ukraine, the defence of dissertation papers for obtaining a scientific degree of a doctor of sciences in most cases is a theoretical one without the possible introduction of the results obtained in the practice of domestic business entities of all forms of ownership. As a result, the growth rate of the wages of workers who successfully defended the dissertation far exceeds the rate of growth of their productivity and efficiency. In some cases, when in the dissertation papers on obtaining the scientific degree of the doctor of sciences highlight the actual issues for society and provide an effective mechanism for their solution, at the stage of preparation of the dissertation work there is "remittance" of doctoral students to foreign companies in order to ensure the further exportation of their intellectual potential abroad.

As regards the low level of influence of the index $\mathrm{X}_{5}$ (real salary index) on the performance indicator $\mathrm{Y}$, this may be due to the conditions of the functioning of the domestic business. That is, an increase in the cost of labour costs may be related not to the increase in the quality of the performed functional responsibilities but to be the result of the introduction of mandatory programs for the protection of the socially unprotected population at the state level (the existence of a tax social benefit, a steady increase in the size of the subsistence minimum and minimum wages, etc.).

Also, one of the conditions for the feasibility of using this group of factors in further research is to verify the presence of multicollinearity. Using the formula to check the presence of multicollinearity between the factors, a significant correlation was found between the $\mathrm{X}_{1}$ indicator (average number of economically active population aged 15-70) and $X_{2}$ (number of graduates from higher education institutions). This is due to the fact that those who graduated from higher education institutions and do not plan to continue postgraduate and doctoral studies in the short and medium term are economically active and replenish the relevant labour market. At the same time, graduates of higher education institutions need to take into account the fact that in today's realities of the domestic labour market availability of a higher education diploma does not guarantee an individual free employment in the chosen specialty owing to the possible lack of correspondence between demand and supply in the labour market, as well as possible lack of relevance of knowledge gained conditions of intensive development of scientific and technological progress.

The calculations also revealed a low level of correlation between the real wage index and the number of persons who obtained the qualification level of a bachelor's, master's, and also a scientific degree of the candidate of sciences (doctor of philosophy), doctor of sciences. This is due to the unwarranted expectations of the indicated persons regarding the possible signif icant increase in their wages in the event of successful completion of the relevant training programs. Thus, in the conditions of employment outside of higher education institutions, the presence of a scientific degree of a candidate of sciences (doctor of philosophy) in the chosen direction of activity can additionally bring the individual only 5\% of the size of the salary, doctor of sciences $-10 \%$. On the other hand, in the case of employment in higher education institutions, the amount of allowances may amount to $15 \%$ and $25 \%$ respectively. However, in the context of reducing the number of potential students and students and the total lack of funds, the indicated allowance may not be charged for the payment of labour to scientific and pedagogical workers. It is also necessary to take into account that if there is a practical value of the prepared dissertation work and a high level of professionalism of a scientific figure in the chosen research direction, the level of his remuneration will be several times or even an order of magnitude higher than the average wage level in the industry. As a result, in order to minimize the cost of paying the single contribution to the Pension Fund of Ukraine (22\% of salaries), personal income tax (18\% of deductions from accrued wages), military salary $(1.5 \%)$, trade union fees $(1 \%$ in case of joining the primary trade union organization), a highly skilled worker indicated by the official payroll will receive a salary within the minimum legal level, in fact, several times or even an order of magnitude higher.

\section{Prognostic trends in the development of the economy and the educational sector}

In order to improve the quality and validity of the calculations on the impact of higher education quality indicators on the gross domestic product, taking into 
account the existing link between the performance indicator and the proposed factors, multicollinearity, indicators "average number of economically active population aged $15-70$ years" and "the real wage index" should be eliminated from the multiple linear regression. Consequently, the regression, according to the views of the experts and taking into account the results of the mathematical processing performed, should at least be as follows:

$$
\mathrm{Y}=\mathrm{A}_{0}+\mathrm{A}_{1}+{ }^{*} \mathrm{X}_{1}+\mathrm{A}_{2}{ }^{*} \mathrm{X}_{2}+\mathrm{A}_{3}{ }^{*} \mathrm{X}_{3} \text {, }
$$

where $\mathrm{Y}$ - gross domestic product at constant prices in 2010, UAH million;

$\mathrm{X}_{1}$ - the number of graduates from institutions of higher education, persons;

$\mathrm{X}_{2}$ - the number of persons who graduated from the postgraduate study;

$\mathrm{X}_{3}$ - the number of persons who have completed doctoral studies, persons.

$A_{0}, A_{1}, A_{2}, A_{3}$ - coefficients.

According to the data given in Table 1, the following function is received:

$Y=1242,46+0,8655 * X_{1}+27,3525 * X_{2}+797,63 * X_{3}$

The calculations of the elasticity coefficients $\left(\mathrm{E}_{\mathrm{yx} 1}=0,4205, \mathrm{E}_{\mathrm{yx} 2}=0,1948, \mathrm{E}_{\mathrm{yx} 3}=0,3835\right)$ indicate that the greatest impact on the gross domestic product is the "number of graduates from higher education institutions". Consequently, the leadership of institutions of higher education must first of all focus on ensuring the maximization of the quality of services rendered to this group of consumers. It is also necessary to take into account that the cost of studying on a budget form for the higher education "bachelor" (on average, about 35 thousand UAH per year) is estimated by state experts to be almost three times higher than the cost of training on a contractual basis. Introducing a phased increase in the cost of training on a contractual basis up to 35 thousand UAH per year at current prices, while simultaneously reducing the number of seats on the budget form of training can lead to a decrease in the demand for educational services of domestic higher education institutions and to increase the number of potential entrants and students who will go to obtain higher education abroad or to the leading central Ukrainian universities, reducing them most contingent of regional higher education institutions.

One can state that the fact that with the constant growth of the subsistence minimum and minimum wages, the expenses for labour remuneration of academic and service workers increased significantly during the last years. At the same time, the share of consolidated budget expenditures on higher education in the structure of total expenditures during 2010-2017 has significantly decreased. Thus, according to the results of 2017 , their share amounted to $3.7 \%$, which is respectively $0.5 \mathrm{pp}$ and $2.9 \mathrm{pp}$ less compared to 2016 and 2010. This indicates the urgent need to develop and implement measures to optimize the labour costs of scientific and pedagogical workers.

\section{Development of measures and directions of optimization of labour costs}

Today's realities in the development of the educational industry require top management of institutions of higher education, especially the regional level, the introduction of a mechanism to minimize labour costs by optimizing the number of pedagogical and scientific and pedagogical workers. When implementing these measures, the leadership of higher education institutions should first of all focus on the quality of services provided to applicants for higher education "bachelor" and "master". At the same time, it is necessary to provide an optimal combination of mastering students and students with theoretical and practical skills from the chosen specialties. At the same time, the implemented complex of measures should not only preserve existing qualitative components of educational and scientific activities but also create an effective model of career development of personnel.

The development of a methodical approach to rating the activity of academic workers, which will allow taking due account of all qualitative and quantitative achievements of employees and the importance of each group of factors in the current conditions of development of the educational branch, is of paramount importance.

The organization of the preparation of processes for evaluating the activities of scientific and pedagogical workers should foresee the formation of a commission with the involvement of both leading figures from higher education institutions and specialists from state authorities, local self-government, public organizations, and leading business structures. Priority responsibilities of this commission should include the analysis of the national and regional labour market and the definition of the level of demand and requirements for the chosen specialty from potential employers; determination of the value and economic expediency of the results of scientific research carried out by academic workers in a certain area of research (participation in international grants, research projects under state orders, other projects for local contracts, obtaining foreign and domestic patents, etc.); realization of comparison of available qualitative characteristics of academic worker with requirements of the market to the level of training of specialists in the chosen specialty; transfer of qualitative results of academic workers into the overall quantitative scale of evaluation and identification of the most competitive workers in a certain segment of the educational services market, etc.

The main task of evaluating the activities of the staff is to establish indicators that can be characterized as general moments, which are equivalent to all employees of institutions of higher education, as well as norms of pedagogical and scientific activity for a particular workplace or position. 
It is interesting to note that there is a Regulation on the rating assessment of the activities of the teaching staff, developed at the Kherson National Technical University (2016). According to this Regulation, the evaluation of the results of the activities of academic workers is carried out in two parts:

- constant activity (coefficient of weight is equal to 0.33 ), which characterizes the qualification potential of the teacher accumulated by him for all time of work; - an active part $(0,67)$ which takes into account professional competence, pedagogical skills, and scientific and creative activity of the teacher over the last five years.

On the example of the Faculty of Economics of the Kherson National Technical University, it was found that the average score for the teaching staff in terms of one person for the results of 2016-2017 amounted to 1174,68 points.

At the same time, if there is a scientific publication in the periodical, which is included in the scientific and metric databases Scopus or Web of Science Core Collection, a scientist and pedagogue will receive only 75 points for each publication, which is $6.4 \%$ of the average score in the calculation per person. This is despite the fact that the state executive authorities together with the top management of institutions of higher education try to establish a close connection between the number of allocated places on the budget form of training and the number of publications of academic workers in periodicals that are included in the scientometric databases Scopus or Web of Science Core Collection. As an example, in order to increase the scientific activity of subordinates, in accordance with the March 2016 Regulations on bonuses for publications in publications that are indexed in the international scientometric databases of the Web of Science Core Collection (other than the Emerging Sources Citation Index) and (or) Scopus (National University of Kyiv-Mohyla Academy, 2016), President of the National University of Kyiv-Mohyla Academy carries out a corresponding bonus of the university employees. The amount of the bonus is calculated for each publication separately, and when determining its size, account is taken: the number of publications by the employee in the publications included in the scientometric databases Scopus and Web of Science Core Collection (except Emerging Sources Citation Index); number of co-authors of publications; quartile magazine according to Scopus's scientometric databases and/or Web of Science.

Taking into account the specifics of the functioning of certain structural subdivisions of the Kherson National Technical University, the results of the conducted assessment can show fundamentally different values among the academic staff of individual departments, which, at the same time, may not be related to the quality of the provided educational services and functional responsibilities that are performed. The above may arise due to the lack of opportunities at the state and regional level to publicize and test the results of research conducted. In order to eliminate these shortcomings in the system of evaluation and creation of a universal university rating, it is necessary to introduce a mechanism for the transfer of activity indicators within each structural subdivision into a single comparative coefficient and compare only the obtained values with the indicators of other units.

Also, in the developed Regulations on the rating assessment of the teaching staff, the level of practical and professional training of academic workers outside the institutions of higher education is almost ignored.

Therefore, in order to improve the quality and validity of the results, a working group is proposed for the development of the relevant Provision, which would include representatives of public authorities, non-governmental organizations, and leading business structures of the respective administrative-territorial unit. It is also necessary to introduce a substantiated methodology for determining the proportion of each of the areas of scientific and pedagogical activity by taking into account the coefficients of competence of each of the experts involved.

To calculate the coefficient of competence of experts, we propose the use of the following formula, developed in previous studies (Tyukhtenko, Makarenko, 2016):

$$
\mathrm{C}=\frac{\tilde{N}_{1}+\tilde{N}_{2}+\ldots+\tilde{N}_{\mathrm{n}}}{\mathrm{n}}
$$

$\mathrm{C}$ - coefficient of competence of experts;

$\mathrm{C}_{1}$ - coefficient, which is assigned depending on the work experience (occupied position);

$\mathrm{C}_{2}$ - coefficient, which is assigned depending on the existing level of education, scientific degree;

$\mathrm{C}_{\mathrm{n}}$ - coefficient, which is assigned depending on the n-factor;

$\mathrm{n}-$ the number of factors on which the qualification level of experts is evaluated.

As an example, for conducting an evaluation of the activities of the academic staff of the Faculty of Economics and Management of the Kherson State University (Kherson, Kherson region, Ukraine), it is proposed to set up an expert commission, which will include: Deputy Director of the Department of Economic Development and Trade of the Kherson Regional State Administration - Head of the Department of Analytics, Planning and Information Compilation, Master's degree, two higher educations (Expert № 1); Head of the Department of Personnel Management of the Main Directorate of the State Fiscal Service of Ukraine in the Kherson region, the Autonomous Republic of Crimea and Sevastopol, Master's degree, and two higher educations (Expert № 2); Vice-Rector of Kherson State 
University for Educational and Scientific-Pedagogical Affairs, Candidate of Economic Sciences, Associate Professor (Expert № 3); Dean of the Faculty of Economics and Management, Kherson State University, Doctor of Economics, Associate Professor (Expert № 4); Head of Kherson Regional InterBranch Council of Trade Unions, Master's degree, two higher educations (Expert № 5); Director of the leading industrial enterprise of "Amalteya" Ltd., Master's degree, two higher educations, Postgraduate Student of correspondence form of study in specialty 051 “Economics” (Expert № 6); Director of the leading industrial enterprise of the leather factory "Platan LTD”, Master's degree, two higher educations (Expert № 7); Chairman of the Board of the Public Organization "Business Association “MY-KHERSONTSI”, Master’s degree (Expert № 8).

Given that each commission expert has a different level of education, experience and, as a consequence, different positions, it is proposed to calculate the competence ratios of commission members in the following way. To calculate the coefficient, which is assigned according to the existing level of education $\left(\mathrm{K}_{1}\right)$, we propose to use the following scale of assessment: persons with the lowest degree of higher education "bachelor" receive 1 point. For all others, their score level of assessment will increase depending on the interval of study, that is: for those with a higher education level "specialist" 2 points, "master" - 3 points, "candidate of sciences (Ph.D.)" - 6 points, "doctor of sciences" -8 points. For individuals with two or more higher educations, there are postgraduate students or doctoral students plus one additional score.

In order to calculate the coefficient, which is assigned depending on the work experience (position held) $\left(\mathrm{K}_{2}\right)$, it is proposed to take into account not only the experience of the work profile of the work group but also the scale of the managerial activity of the expert (the number of subordinates, the production capacity of the departmental subdivision and the subject of management in general, etc.).

Taking into account that among the main requirements for obtaining the academic title of associate professor and professor, there is the presence of the corresponding scientific degree and work experience, and also that the indicated qualitative components of an academic worker are taken into account in the subsequent career growth and are attributes of directly scientific and pedagogical activities, their additional consideration when evaluating the competence of experts is inappropriate.

Table 2 gives an example of the calculation of the competence coefficients of the experts of the proposed working group for the development of the Regulations on the rating assessment of the teaching staff.
Table 2

Calculation of the coefficients of competence

\begin{tabular}{|c|c|c|c|c|c|}
\hline Expert & Mark & $\mathrm{K}_{1}$ & Mark & $\mathrm{K}_{2}$ & $\frac{\sum \hat{\mathrm{E}}}{2}$ \\
\hline № 1 & 4 & $\frac{4}{38}$ & 4 & $\frac{4}{31}$ & 0,117148 \\
\hline$№ 2$ & 4 & $\frac{4}{38}$ & 3 & $\frac{3}{31}$ & 0,101019 \\
\hline № 3 & 6 & $\frac{6}{38}$ & 5 & $\frac{5}{31}$ & 0,159592 \\
\hline № 4 & 8 & $\frac{8}{38}$ & 2 & $\frac{2}{31}$ & 0,137521 \\
\hline № 5 & 4 & $\frac{4}{38}$ & 5 & $\frac{5}{31}$ & 0,133277 \\
\hline № 6 & 5 & $\frac{5}{38}$ & 6 & $\frac{6}{31}$ & 0,162563 \\
\hline № 7 & 4 & $\frac{4}{38}$ & 4 & $\frac{4}{31}$ & 0,117148 \\
\hline № 8 & 3 & $\frac{3}{38}$ & 2 & $\frac{2}{31}$ & 0,071732 \\
\hline Amount & 38 & 1 & 31 & 1 & 1 \\
\hline
\end{tabular}

Source: developed by the authors

The example of determining the competencies of the experts in Table 2 allows taking into account the individual level of practical and scientific training of each of the respondents and reducing the level of error when using the intuitive group of methods.

At the next stage, it is necessary to define a range of indicators, which allow conducting an assessment of the effectiveness of the activities of scientific and pedagogical workers to build a relationship between the indicated indicators and the professional career of the individual. In our view, the key indicators by which evaluation of academic workers of institutions of higher education in economics and management can be divided into two groups are: qualitative (communication skills, leadership skills, persistence, timeliness of the executed decisions, complexity of functional duties, activity and initiative at work, etc.) and quantitative (work experience in the profile and in institutions of higher education, level of education, average academic load, participation in R\&D, average duration of the course overseas internship; total volume of trained papers (in printed sheets) over the last five years: publications in periodicals included in Scopus science and metric databases or Web of Science Core Collection; publications in scientific journals included in the list of scientific journals Ukraine, or in a foreign peer-reviewed scientific publication, teaching and methodological works, monographs, abstracts, author's programs, etc.).

Taking into account that all groups of indicators are important in assessing the effectiveness of subordinate employees, the expert group established should determine the specific weight of the influence of each of the factors on the overall performance indicator, in this case, on the level of competitiveness of the academic worker. As an example, you can propose to use their rankings by each of the experts from greater to smaller in the following way: 
Expert number 1 : factor $1>$ factor $2=$ factor $3>$ factor $4=\ldots>$ factor $n$

Expert number 2 : factor $4>$ factor $3=$ factor $1>$ factor $2=\ldots>$ factor $n$

Expert number 8: factor $3>$ factor $4=$ factor $2>$ factor $1=\ldots>$ factor $n$

Using the calculated coefficient of competence and evaluating the score of each of the factors (depending on the determined range of fluctuations between factors), it is necessary to determine the relative importance of each of them for the level of competitiveness of the academic worker.

The next step is to conduct an individual assessment of academic workers for each of the identified factors. For a qualitative group of indicators, it is suggested to use point assessment using the following method: from 1 (not developed quality) to 10 (significantly improved quality).

The next step is to use a two-step technique, and this will allow all metrics to be translated into a single measurement scale. In the first stage, the rating assessment is carried out on the basis of the calculation of relative deviations of the indicators of each employee from the best values of such indicators of other employees of this area of research by the formula:

$$
R j=\frac{X_{\text {max }}-X_{i j}}{X_{\text {max }}-X_{\text {min }}},
$$

$R_{j}$ - rating of a specific academic worker for each of the indicators that characterize a separate scientific and pedagogical component;

$\mathrm{Xij}$ - the value of the $\mathrm{i}$-th $\mathrm{j}$-th employee figure;

$\mathrm{Xmax}$ - the maximum value of the $\mathrm{i}$-th indicator;

$\mathrm{Xmin}$ - the minimum value of the $\mathrm{i}$-th indicator.

At the second stage, the overall rating of a particular employee is determined on all indicators, taking into account their specific weight of influence on the resultant factor, using the formula:

$$
\mathrm{R}_{\mathrm{cpj}}=\Sigma \mathrm{R}_{\mathrm{j}}^{*} \mathrm{q}_{\mathrm{i}}
$$

$\mathrm{q}_{\mathrm{i}}$ - the specific gravity of the influence of the $\mathrm{i}$-th indicator in the aggregate of the indicators on which the calculation is performed.

The results of the calculation determine the place of a particular employee in the ranking of the selected group of indicators. The best one is a worker whose rating value is the lowest.

Table 3 provides an example of calculations of the values of the rating assessment of academic workers.

Also, with the introduction of a rating assessment of the activities of academic workers and its attachment to the development of professional careers, it is necessary to avoid possible professional burnout due to overload.

For managers of institutions of higher education, the permanent development and implementation of a set of measures to improve the management of time resources are also one of the main directions for increasing the efficiency of activities through the growth of labour productivity and more efficient use of existing productive assets.

\section{Conclusions and recommendations for further research}

The results of the conducted research testify to the necessity of introducing a set of measures for optimization of labour costs for academic workers of institutions of higher education without worsening the quality of provided educational services. To maintain the existing intellectual potential justified the introduction of an organizational and economic system for optimizing labour costs, which should consist of the following five main stages: collecting information,

Table 3

\begin{tabular}{|c|c|c|c|c|c|c|c|c|c|}
\hline $\begin{array}{c}\text { Academic } \\
\text { worker }\end{array}$ & $\begin{array}{l}\text { Work } \\
\text { experience } \\
\text { by profile, } \\
\text { month }\end{array}$ & Coefficient & $\begin{array}{c}\text { Experience } \\
\text { in higher } \\
\text { education } \\
\text { institutions, m. }\end{array}$ & Coefficient & $\begin{array}{c}\text { Education, } \\
\text { points }\end{array}$ & Coefficient & ...... & $\begin{array}{l}\text { The overall ranking } \\
\text { is based on the } \\
\text { specific gravity of } \\
\text { the factors }\end{array}$ & Place \\
\hline № 1 & 82 & 0 & 69 & 0,89 & 7 & 0,25 & $\ldots$ & 0,127 & 1 \\
\hline № 2 & 0 & 1 & 131 & 0,565 & 6 & 0,5 & $\ldots$ & 0,282 & 4 \\
\hline № 3 & 40 & 0,512 & 123 & 0,607 & 8 & 0 & $\ldots$ & 0,138 & 2 \\
\hline № 4 & 0 & 1 & 239 & 0 & 6 & 0,5 & $\ldots$ & 0,225 & 3 \\
\hline № 5 & 52 & 0,366 & 48 & 1 & 4 & 1 & $\ldots$ & 0,305 & 5 \\
\hline \multirow[t]{3}{*}{$\begin{array}{l}\text { Specific } \\
\text { gravity } \\
\text { of factors }\end{array}$} & 0,15 & & 0,1 & & 0,15 & & ... & & \\
\hline & $\operatorname{Max}=82$ & & $\operatorname{Max}=239$ & & $\operatorname{Max}=8$ & & $\ldots$ & & \\
\hline & $\operatorname{Min}=0$ & & $\operatorname{Min}=48$ & & $\operatorname{Min}=4$ & & $\ldots$ & & \\
\hline
\end{tabular}

An example of calculations of the values of the rating assessment of academic workers

Source: developed by the authors 
processing information received using expert and econometric and mathematical models, calculating the predictive values of factors and productive indicator, development of measures and directions of optimization of labour costs, development of a system of planning career development of personnel. It has been revealed that the lack of a sound methodological approach to employee rating and appropriate means of motivation for professional development can lead to the loss of existing intellectual potential and competitive positions of higher education institutions in the market for educational services in general.

In order to improve the quality and validity of the results, a working group is proposed for the development of the relevant Regulation, which would include representatives of public authorities, nongovernmental organizations and leading business structures of the respective administrative-territorial unit. It is also necessary to introduce a substantiated methodology for determining the proportion of each of the areas of scientific and pedagogical activity by taking into account the coefficients of competence of each of the experts involved.

A further study of the mechanism of determining the optimal predictive model, taking into account the influence of the shadow sector on the official statistical indicators of the development of the economy and the educational sector, in particular, deserves further study.

\section{References:}

Beztelesna,L.I.,Pecheniuk,A.V.(2016). Upravlinnia profesiinym rozvytkomnaukovo-pedahohichnykh pratsivnykiv: monohrafiia [Management of the professional development of academic staff: a monograph]. Rivne: NUVHP. (in Ukrainian)

Derkach, A. A., Zazykyn, V. H., Markova, A. K. (2000). Psykholohyia razvytyia professyonala: uchebnoe posobye [Psychology of professional development: a textbook]. Moscow: Nauka. (in Russian)

Derzhavna sluzhba statystyky Ukrainy (2018). Ekonomichna aktyvnist naselennia Ukrainy 2017: Statystychnyi zbirnyk [Economic activity of the population of Ukraine 2017: Statistical collection]. Retrieved from: http://ukrstat.gov.ua (accessed 11 July 2018)

Derzhavna sluzhba statystyky Ukrainy (2018). Osnovni pokaznyky diialnosti vyshchykh navchalnykh zakladiv Ukrainy na pochatok 2016/17 navchalnoho roku [Main indicators of activity of higher educational institutions of Ukraine at the beginning of 2016/17 academic year]. Retrieved from: http://ukrstat.gov.ua (accessed 18 July 2018)

Herasymenko, O. O. (2003). Ekonomichnyi mekhanizm stymuliuvannia pratsi u sferi naukovoi ta naukovo-tekhnichnoi diialnosti (na prykladi vyshchykh navchalnykh zakladiv Ukrainy) [Economical mechanism of stimulation of labor in the field of scientific and scientific-technical activity (on the example of higher educational institutions of Ukraine) ] (PhD Thesis), Kyiv: Kyiv National Taras Shevchenko University.

Kaminskyi, B. A. (2006). Upravlinnia personalom vyshchykh navchalnykh zakladiv [Personnel management of higher education institutions] (PhD Thesis), Lviv: Institute of regional research of NAS of Ukraine.

Kherson National Technical University (2016). Polozhennia pro reitynhove otsiniuvannia diialnosti profesorsko-vykladatskoho skladu Khersonskoho natsionalnoho tekhnichnoho universytetu [Regulations on rating assessment of the Kherson National Technical University teaching staff activity]. Retrieved from: http://kntu.net.ua/ukr/content/download/48525/285531/ file/\%D0\%B4\%D0\%BE\%D0\%B4\%D0\%B0\%D1\%82\%D0\%BE\%D0\%BA\%20\%E2\%84\%96\%205.pdf

Lozovetska, V. T. (2015). Profesiina kariera osobystosti v suchasnykh umovakh: monohrafiia [Professional career of the individual in modern conditions: monograph]. Kyiv: Institute of Vocational Education NAPS of Ukraine. (in Ukrainian) Mokin, B. I., Marymonchyk, Yu. V. (2004). Metodolohichni osnovy materialnoho stymuliuvannia efektyvnoi diialnosti personalu VNZ iz pidhotovky naukovo-pedahohichnykh kadriv ta stvorennia yakisnoi naukovoi produktsii [Methodological basis of material incentives for effective operation of university personnel training of the teaching staff and the creation of high-quality scientific products]. Visnyk VPI, 2, 26-31.

National University of "Kyiv-Mohyla Academy" (2016). Premiiuvannia spivrobitnykiv NaUKMA za publikatsii u vydanniakh, shcho indeksuiutsia $v$ naukometrychnykh bazakh [Awarding of employees of the National University "Kyiv-Mohyla Academy" for publication in editions that are indexed in science-based databases]. Retrieved from: http://www.library.ukma.edu.ua/index.php?id=single\&no_cache $=1 \&$ tx_ttnews[tt_news]=974

Obmok, O. H. (2014). Oblik rezultativ reitynhovoi otsinky diialnosti naukovo-pedahohichnykh pratsivnykiv [Accounting of the rating assessment results of the activities of Academic staff]. Visnyk ahrarnoi nauky Prychornomoria, 3(80), 83-90.

Pivniak, H., Aziukovskyi, O., Trehub, M., Bardas, A. (2017). Formuvannia derzhavnoho zamovlennia na pidhotovku fakhivtsivinzhenernykh ta fizyko-matematychnykh spetsialnostei [Formation of the state order for training of professionals of engineering, physical and mathematical specialties]. Vyshcha shkola: Naukovo-praktychne vydannia, 2, (151), $17-32$.

Skibitska, O. V. (2004). Stymuliuvannia rozvytku tvorchoho potentsialu pratsivnykiv vyshchoi shkoly [Stimulating the development of creative potential of high school employees] (PhD Thesis), Kyiv: Institute of regional research of NAS of Ukraine.

Tsymbaliuk, S. O. (2017). Determinanty trudovoi aktyvnosti personalu v systemi motyvatsii [Determinants of personnel labor activity within the system of motivation]. Aktualni problemy ekonomiky, 1(187), $264-272$.

Tyukhtenko, N.A., Makarenko, S. M. (2016). Vykorystannia ekonomiko-matematychnykh modelei pry planuvanni chyselnosti ta skladu pratsivnykiv na pidpryiemstvakh usikh form vlasnosti [Economic and mathematic models for staff planning at enterprises of all ownership forms]. Aktualni problemy ekonomiky, 1(175), 435-442. 